DR-5

\title{
APPLICATION OF AMINOPHENYLBORONIC ACID CONJUGATED WITH PROTEIN CARRIER FOR APTACHROMATOGRAPHIC DETECTION OF LEAD IONS
}

\author{
A. N. Berlina, N. S. Komova, A. V. Zherdev, B. B. Dzantiev
}

\section{A. N. Bach Institute of Biochemistry, Research Center of Biotechnology of the Russian Academy of Sciences, Leninsky prospect 33, Moscow 119071, Russia. E-mail: berlina.anna@ gmail.com}

Abstract. Currently, the detection of heavy metal ions plays an important role in environmental monitoring. A large number of instrumental methods are used to determine this contaminant, such as mass-spectrometry with inductively coupled plasma, high performance liquid chromatography, and others [1]. However, it is necessary to develop new and simple methods for determining lead. A large number of nanoparticles and receptor molecules that directly interact with heavy metal cations, such as mercury and lead, have been tested in recent years [2]. The development of quick and simple methods for their detection is in demand in many countries of the world.

This work is devoted to the study of interactions between lead ions, aptamers on the surface of gold particles modified by them, in a homogeneous medium and using chromatographic separation of complexes. For the development of chromatographic rapid methods, a protein-chelator conjugate is required. The most difficult part in such a structure is a chelating agent. Derivatives of ethylenediamine $\mathrm{N}, \mathrm{N}, \mathrm{N}$ ', N'-tetraacetic acid are most often found in the literature in the described methods [3]. The objective of this work is to use aminophenylboronic acid for this purpose and show the analytical capabilities of this system. The results showed that this compound can be used. The detection limit of lead ions was $5 \mathrm{ng} / \mathrm{ml}$, which corresponds to the established standards for drinking water.

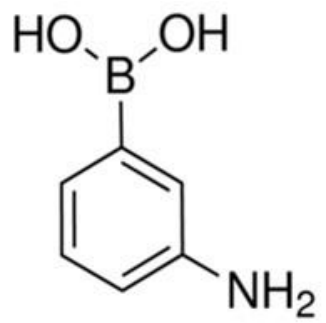

Figure 1. 3-Animophenylboronic acid

\section{References}

1. Standard C33, A.S.T.M., "Specification for Concrete Aggregates" ASTM International, West Conshohocken, PA, 2006, DOI: 10.1520/C0033-03R06, www.astm.org., 2003 (2006).

2. Berlina, A.N., Progress in rapid optical assays for heavy metal ions based on the use of nanoparticles and receptor molecules / A.V. Zherdev, B.B. Dzantiev // Microchimica Acta. - 2019. - Vol. 186, Iss. 3. 172.

3. High sensitive gold-nanoparticle based lateral flow Immunodevice for Cd2+ detection in drinking waters / López_Marzo, A.M., J. Pons, D.A. Blake // Biosensors and Bioelectronics/ - 2013. - Vol. 47. - P. 190-198.

This work was financially supported by Russian Science Foundation (project \# 19-44-02020). 